\title{
The Position of the Jews in Egypt and Syria in the Late Middle Ages
}

The legal position of the Jews in the medieval Muslim world was clearly defined in Islamic law: Jews are considered part of "the protected people" (Arabic: ahl-aldhimma, or: dhimmis), together with other non-Muslim groups who live under Islamic rule, such as Christians, whose religion is acceptable to Islam. As dhimmis, individual Jews have the right to observe their faith and to run their affairs without interference, as well as the right to protection for their life and property, as long as they take upon themselves two commitments:

a) The regular payment of the poll tax (jizya) to the Muslim state.

b) Observance of a list of discriminatory laws, called "the Pact of Umar," attributed to one of the early Muslim caliphs. These laws included, for instance, symbolic acts meant to humiliate and distinguish the dhimmis from the Muslims, such as the requirement to rise in the presence of Muslims when the latter was sitting down, to refrain from riding horses or using saddles and bearing arms, to construct their houses at a lower elevation than those belonging to Muslims, and to distinguish themselves from Muslims by avoiding the use of honorific names (such as names beginning with Abū), and, of special importance-by dressing in distinct garb. In addition, the "Pact of Umar" also prohibited non-Muslims from building new houses of worship and even from making repairs to existing buildings that had fallen into ruin, or displaying their religion publicly. ${ }^{1}$

We may say that in general, with few exceptions, this basic Islamic attitude toward Jews was observed in the breach during the Middle Ages. This paper, however, will be mainly focused on the situation of the Jews in the heartland of the Middle East in the late Middle Ages, in Egypt and Syria (including the land of Israel) under Mamluk rule, between 1250 and 1517.

It is widely accepted among scholars that the Mamluk period witnessed a significant deterioration in the situation of the Jews in Egypt and Syria. All historical sources seem to indicate that the Mamluk period was indeed a low point for Jews in almost every aspect of life. However, in order to grasp the situation of

1 M. R. Cohen, Under Crescent and Cross: The Jews in the Middle Ages (Princeton: Princeton University Press, 1994), 52-72.

Ә OpenAccess. () 2020 Amir Mazor, published by De Gruyter. (cc) BY-NC-ND This work is licensed under the Creative Commons Attribution-NonCommercial-NoDerivatives 4.0 License. 
the Jews more clearly, I will examine the situation in its true social and cultural contexts, and in relative attitude.

The attitude of the Mamluk sultans toward Jews and Christians stood in sharp contrast to the policies of the preceding heterodox Shī'i Fatimid Caliphs, who ruled between 969 and 1171. Except for a short period under the caliph al-Ḥākim bi-Amr Allāh (1007-1021), in which dhimmīs were persecuted, during the long Fatimid period Jews and Christians enjoyed a distinguished position. Cairo Genizah documents indicate that the requirements for dhimmis to wear distinguishing clothing, one of the better known laws of the "Pact of Umar," were not normally enforced, nor were other discriminatory laws. Moreover, Jews were employed as high state officials and physicians. ${ }^{2}$

The situation of the Jews worsened under the Ayyubid Sultanate, founded in Egypt by Saladin in 1171. Deposing the Shì'̄i Fatimid Caliphate after two hundred years, Saladin restored Sunnism as the only legitimate religious rite of the state. In order to strengthen Sunnism in Egypt and Syria and to justify his image as a holy warrior (mujāhid) against the infidel Crusaders, his rule inclined to orthodox zeal, including the implementation of some of the Pact of Umar laws. For instance, Muslim historians note that during Saladin's reign, for the first time, dhimmis were not allowed to ride on mules (in addition to horses, which was always forbidden). ${ }^{3}$ Both Muslim sources and Jewish sources-that is, the Cairo Genizah documents-indicate that toward the end of the Ayyubid period, around the mid-thirteenth century, Jews in Cairo wore distinctive yellow marks on their turbans, whereas Christians wore their distinctive belt, the zunnār. ${ }^{4}$

The pressure on the non-Muslims became much stronger in the Mamluk period. This was due to several circumstances, mainly political and economic. First, the offensive policy against the Crusades-conducted by the early Mamluk sultans-increased the hatred felt by Muslims against Christians, and-to a lesser extent-also against the infidel Jews. Second, the economic crises that befell Egypt due to the Mongol invasions from the north, alongside severe epidemics

2 Cf. S. D. Goitein, A Mediterranean Society: The Jewish Communities of the Arab World as Portrayed in the Documents of the Cairo Geniza (Berkeley: University of California Press, 1967-1993), 2:285-87; 2:374-80; N. Stillman, "The non-Muslim Communities: the Jewish Community," in The Cambridge History of Egypt: 640-1517, ed. C. F. Petry (Cambridge: Cambridge University Press, 1998), 201.

3 A. b. 'Alī al-Maqrīzī, Kitāb al-Sulūk li-Ma'rifat al-Duwal wa-al-Mulūk (Cairo: Lajnat al-Ta'līf wa al-Tarjama wa al-Nashr, 1934-1973(, 1:77.

4 A. b. 'Alī al-Maqrīzī, al-Mawā' 'iz wa-l-I'tibār bi-Dhikr al-Khițaț wa-l-Āthār fī Miṣr wa-l-Qāhira (Cairo: Bulaq, 1854), 1:367, 1.29; Goitein, A Mediterranean Society, 2:288; N. Stillman, The Jews of Arab Lands: A History and Source Book (Philadelphia: Jewish Publication Society of America, 1979), 68; Stillman, “The non-Muslim Communities,” 207-8. 
and droughts, increased the frustration of the people and brought about religious persecution. Finally, and perhaps the most important factor, is related to the nature and origins of the Mamluk regime. The Mamluk rulers were initially non-Muslim military slaves who originated in the north-eastern areas of the Muslim world and beyond. They were imported to the lands of Islam from these regions as young boys and were acculturated as Muslims. Thus, they were anxious to prove their loyalty to their new religion and to gain the support of the Muslim religious scholars ('ulamá') in order to legitimate and strengthen their rule. Hence, they tended to accept the demands of the 'ulamá' and the people, and to increase the burden on the dhimmis.

Therefore, during this long period, Sultans declared again and again the renewal of the discriminatory laws, most of them originating in known ordinances of the "Pact of Umar," but sometimes, new restrictions were added. Among these laws were the prohibition of Jews and Christians from riding mules, and sometimes even donkeys, and the dismissal of dhimmi officials from the state bureaucracy. The most innovative and-from a historical perspective-perhaps the most terrifying law, concerned the distinguishing color of the dhimmis' clothing. Jews were obliged to wear yellow turbans. ${ }^{5}$ The color yellow began to be identified with Jews for the first time in eleventh-century Baghdad. In Egypt, as we mentioned, Jews were ordered to bear yellow marks on their turbans in the mid-thirteenth century, though we do not know for how long this restriction was implemented. However, it was only in the Mamluk period that yellow was identified exclusively, distinctively, and consistently with the Jews, whereas other colors became identified with other religious groups: Christians with blue and Samaritans with red. Several testimonies of Christian European travelers, as well as Muslim and Jewish sources, indicate unequivocally that Jews in Egypt and Syria wore yellow clothes, whereas Christian and Samaritans wore blue and red respectively. ${ }^{6}$ Similarly, we have sufficient indications to conclude that the law that prohibited Jews and Christians from riding horses and mules was also enforced. Dhimmis were allowed to ride donkeys inside the cities during the fourteenth century, while in the fifteenth century, dhimmis were allowed to ride donkeys only outside the cities. ${ }^{7}$ One should bear in mind, however, that Muslims who were not part of the Mamluk elite were also prohibited from riding horses and sometimes even mules.

5 On the persecutions of Jews in the Mamluk period, see: E. Ashtor and R. Amitai, "Mamluks," in Encyclopedia Judaica (Jerusalem: Keter, 2007), 13:438-41.

6 E. Ashtor, The History of the Jews in Egypt and Syria under Mamluk Rule (Jerusalem: Mossad Ha-Rav Kook, 1944-1970), 2:210-14 [Hebrew].

7 Ashtor, History, 2:214-16. 
Popular riots accompanied state policy. In cities like Alexandria and Cairo, people attacked and destroyed parts of dhimmī buildings that were higher than those of the Muslims. Christians and Jews were attacked in the streets by mobs. Although synagogues appear to have escaped unscathed during most attacks on dhimmī houses of prayer, Muslim and Jewish sources attest that at the beginning of the fourteenth century, synagogues were closed and Jews forbidden to pray in them for about ten years. We do know, however, that two synagogues were demolished by the state during this period: a Karaite synagogue in Damascus in 1321 and a Rabbanite synagogue in Dammūh, near Cairo, in 1498. In 1442 a partial destruction of a Rabbanite synagogue in Fusțāt had been carried out by the authorities after an anti-Islamic blasphemy was discovered in its dais, and in 1474, the synagogue in Jerusalem was demolished by the people but was renovated based on the sultan's order. ${ }^{8}$

In the fifteenth century, due to the deteriorating economic situation, the imposition of heavy taxes on the dhimmis became more common. Sultans increased the poll tax of the dhimmis, imposed tariffs on the production and consumption of wine and on family events and costumes. ${ }^{9}$ The economic crises brought about a clear demographic decline in the Jewish population. Jewish communities in little towns dwindled and sometimes vanished. ${ }^{10}$ This development is especially lamentable, since Egypt had been a prominent center for Jews since the last quarter of the tenth century, with the establishment of the new city of Cairo as the capital of the Fatimid Caliphate.

The rise of Islamic zeal in the Mamluk period was reflected also by antidhimmi polemical literature and responsa (fatwas) that flourished. These works were written by important 'ulam $\bar{a}$ ' and called for an increase to the pres-

8 Ashtor, History, 2:401-15, 2:503; D. Arad, "Being a Jew Under the Mamluks: Some Coping Strategies," in Muslim-Jewish Relations in the Middle Islamic Period, ed. S. Conermann and B. Walker (Göttingen: V\&R unipress; Bonn University Press, 2017), 22-23; T. el-Leithy, "Sufis, Copts and the Politics of Piety: Moral Regulation in Fourteenth Century Upper Egypt," in Le développement de soufisme en Égypte a l'époque mamelouke, ed. R. McGregor and A. Sabra (Cairo: Institute français d'archéologie orientale, 2006), 80n22; M. R. Cohen, "Jews in the Mamlūk Environment: the Crisis of 1442 (a Geniza study, T-S. AS 150.3),” Bulletin of the School of Oriental and African Studies 47 (1984): 425-28; J. Kraemer, "A Jewish Cult of the Saints in Fātimid Egypt," in L'Egypte Fatimide: son art et son histoire, ed. M. Barrucand (Paris: Presses de l'Université de Paris-Sorbonne, 1999), 598.

9 Ashtor, History, 2:310-16.

10 For a recent survey of Jewish communities in Mamluk Egypt, see: D. Arad, "The Musta'rib Jews in Syria, Palestine and Egypt 1330-1700" (Ph.D. thesis, Hebrew University of Jerusalem, 2013), 26-36 [Hebrew]. 
sure on the dhimmiss, to humiliate them and to keep them away from Muslim society. $^{11}$

The deteriorating status of Jews could be also examined through the prism of Jewish physicians. During the Mamluk period, a generally increasing opposition of orthodox Muslims to the treatment of Muslim patients by Jewish and Christian physicians is noticeable. Muslim scholars warn in their writings against hiring non-Muslim physicians as well as against buying medicine from them. It also seems that more Muslim physicians refused to teach non-Muslims. ${ }^{12}$ In 1448 , the Mamluk Sultan even issued a decree that for the first time prohibited nonMuslim physicians from treating Muslims. The decree was not enforced for too long. However, it marks, as noted by Norman Stillman, “a momentous reversal of the longstanding non-confessional nature of the medical profession in the Islamic world." Up to then, the medical occupation in the Muslim world had always been nonsectarian, characterized by a universal spirit, in which Jews, Christians, and Muslims, as Goitein puts it, "formed a spiritual brotherhood that transcended the barriers of religion, language and countries." 13 Indeed, the decline in the status of the Jewish physicians is shown by the dwindling number of court physicians and dynasties of court physicians in the Mamluk period, compared to the previous Fatimid and Ayyubid periods. In addition, Jews could not serve in the office of "Head of the Physicians" in Cairo. They also found it difficult to serve in public hospitals. ${ }^{14}$

Now, despite the clear deterioration of the situation of the Jews in Mamluk Egypt and Syria, in order to evaluate the situation of the Jews more correctly, one has to take into consideration several issues regarding the government and the

11 For important anti-dhimmī literature that emerged and flourished during the first half of the fourteenth century, targeted mostly against Christian Copts, see: el-Leithy, "Sufis," 76n6. For selected articles on this literature, see: Cohen, Under Crescent and Cross, 229n101.

12 M. Perlmann, "Notes on the Position of Jewish Physicians in Medieval Muslim Countries," Israel Oriental Studies 2 (1972): 316-19; S. W. Baron, A Social and Religious History of the Jews (New York: Columbia University Press, 1980), 17:175, 378n61; E. Ashtor, "Prolegomena to the Medieval History of Oriental Jewry,” Jewish Quarterly Review 50, no. 2 (1959): 154-55; Ashtor, History, 1:107-8; 1:341-43; Stillman, The Jews of Arab Lands, 72; D. Behrens-Abouseif, Fath Allāh and Abū Zakariyya: Physicians Under the Mamluks (Cairo: Institut français d'archéologie orientale, 1987), 14; P. B. Lewicka, "Healer, Scholar, Conspirator: The Jewish Physician in the Arabic-Islamic Discourse of the Mamluk Period," in Muslim-Jewish Relations in the Middle Islamic Period, ed. S. Conermann (Göttingen: V\&R unipress; Bonn University Press, 2017), 121-44.

13 Stillman, "The Jewish Community," 209; Stillman, The Jews of Arab Lands, 71-72; Goitein, A Mediterranean Society, 2:241.

14 A. Mazor, "Jewish Court Physicians in the Mamluk Sultanate during the First Half of the $8^{\text {th }} /$ $14^{\text {th }}$ Century," Medieval Encounters 20 (2014): 64-65n92. 
people's attitude to dhimmiss and to Jews in particular. First, most of the discriminatory and humiliating regulations against dhimmis were enforced for limited periods or not at all. This is admitted by contemporary Muslim historians and that is the reason for the need to reinforce these laws again and again. This is especially true regarding the dismissal of dhimmī bureaucrats, since the Mamluk sultanate could not function properly without them. ${ }^{15}$ Jewish bureaucrats continued to serve in state offices and in the households of Mamluk officers throughout the Mamluk period, though their number and status was much lower than those of the Christians. Jews served mainly in financial offices, such as customs officials, state lessees, and especially as money changers. ${ }^{16}$ Second, generally, dhimmis received the protection of the authorities against the attacks of Muslim figures and the mob. Muslim chronicles mention several episodes in this regard. For instance, in 1315, when a Muslim rode along the streets of Cairo, striking Jews or Christians who passed by him with his sword, he was captured and beheaded. ${ }^{17}$ Documents from the archive of the Jewish community in Cairo indicate that Jews were permitted to renovate their synagogues in Cairo several times, when the case was found permissible by Islamic law. ${ }^{18}$

Third, the wearing of yellow clothes should be put in the right cultural context. This practice was not considered an act of outstanding humiliation for Jews, in stark contrast to medieval and modern Europe. Whereas in late medieval Europe Jews were a tiny isolated minority, different in its external appearance from the vast majority of the Christian population, in the Islamicate society of the Mamluk sultanate, there were several ethnic and class groups, each one adopted a color and other external features of its own, which were considered a mark of identity and, to a certain extent, a sign of self-definition. ${ }^{19}$ The streets of fifteenth-century Cairo, Jerusalem, or Damascus, were a cultural mosaic embodied in external features. The members of the Mamluk elite were identified by the horses they rode on, their distinctive headgear and their fancy robes. The Muslim religious elite, the ulamā', were discerned by their wide white turbans, the Christians by their blue turbans, the Samaritans by their red ones, the Georgians by

15 Al-Maqrīzì, Sulūk, 2:924; D. P. Little, "Coptic Conversion to Islam under the Bahri Mamluks, 692-755/1293-1354," Bulletin of the School of Oriental and African Studies 39, no. 3 (1976): 54. 16 Ashtor, History, 2:170, 2:176-77. Most of the Jews mentioned in contemporary Muslim sources were money changers (șayrafīs). See, for instance, Behrens-Abouseif, Fath Allāh, 23; Ashtor, History, 1:205, 2:29n9, 91-93, 177.

17 Al-Maqrīzī, Sulūk, 2:139-40.

18 Arad, "Being a Jew," 26-27.

19 Ibid., 28; Cohen, Under Crescent, 110-11. 
their black turbans, and the Jews by their yellow ones. Jews, hence, were only one group among several others.

Moreover, the yellow clothes were much less inflammatory than the blue clothes of the Christians. It was the dominant community of the Christians that formed the target of most mob riots. This was due to the fact that they occupied the highest positions in the state bureaucracy. Despite Jews also being affected, since they were part of the dhimmis, they were only secondary victims of the anti-dhimmi decrees and riots. It was mainly churches and monasteries that were destroyed in Mamluk Egypt. Instructive examples of the better position of the Jews are cases mentioned in contemporary Islamic sources, in which Christians borrowed the yellow clothes of Jews in order to escape the rage of the mob. ${ }^{20}$

Christian Copts were also the main target for conversion. Though conversion was definitely a more common phenomenon among Jews, too, compared to preMamluk periods, their number was much lower than the Copts and included mainly individuals such as merchants and especially prominent physicians. In contrast, numerous Christian state officials converted in order to maintain their high positions and offices. It seems that the middle of the fourteenth century marks the turning point after which the majority of the population in Egypt, for the first time, became Muslim. ${ }^{21}$

Similarly, anti-dhimmī polemics were not written particularly against Jews but against dhimmiss in general, and in fact, mainly against the majority among the infidels-the Christians. In addition, they were written precisely because reality stood, to a large extent, in contradiction to the ideal of these Islamic theologians. It is these very same parameters that were different in Christian Europe at that time: polemical literature was written only against the single unique big "infidel" majority-the Jews; anti-Jewish works were not only an ideal but in many cases obligatory state laws. ${ }^{22}$

Another aspect of the situation of the Jews in Mamluk Egypt that differed from that of their co-religionists in Christian Europe is related to the extent of Jewish integration into general society. The Jews in Mamluk Egypt and Syria by no means were an isolated community. They never lived in total "ghettolike" isolation as in Europe. There were mosques and other Islamic institutions in the Jewish districts in Muslim cities. ${ }^{23}$ Jews played an integral part in official

20 Little, “Coptic Conversion,” 564; Ashtor, History, 1:338-39; al-Maqrīzī, Khițaț, 2:516, 1.26-7.

21 Little, "Coptic Conversion," 567-69.

22 Ashtor, History, 1:104ff; 209-10; Cohen, Under Crescent, 52.

23 I. M. Lapidus, Muslim Cities in the Later Middle Ages (Cambridge: Harvard University Press, 1967), 85-86, 271; S. D. Goitein, "Cairo: An Islamic City in the Light of the Geniza Docu- 
public and religious events and ceremonies such as royal processions and coronations, prayers for rain and for the inundation of the Nile. Jews, together with Christians and Muslims, also used to worship at the same sacred sites; they participated in joyous and sorrowful "national" events, and they still maintained social, cultural, and intellectual contacts with the Muslim environment. ${ }^{24}$ Whereas during the Black Death in the mid-fourteenth century European Jews fell victims to massive pogroms and were believed to have poisoned wells "in the attempt to destroy Christian civilization," nowhere in the Mamluk Sultanate at that time were Jews blamed for the epidemic, which was perceived as a natural disaster. Moreover, in Damascus, Muslims, Christians, and Jews prayed together, pleading the one God for salvation and the removal of the evil destiny. ${ }^{25}$

In light of all the above mentioned, could we speak of antisemitism in the Mamluk period? According to most scholars, the answer to this question is negative. Antisemitism, understood as irrational belief in a malevolent, violent, antisocial Jewish alliance with satanic forces seeking to control the world, did not exist in the Mamluk Sultanate, or in the medieval Muslim world in general. This is not to say that there are not anti-Jewish notions, instilled in Islamic tradition from its inception, including the Qur'an and the Islamic oral tradition (Hadith), which originated in Muhammad's conflict with the Jews of Medina. However, negative depictions of Jews (mainly as wicked and treacherous) never seem terribly effectual or possess any of the demonic qualities attributed to them in medieval Christian literature. Anti-Jewish propaganda seem to appear in the medieval Muslim world mainly when a Jew was perceived to have egregiously transgressed the boundaries of propriety as stipulated in the "Pact of 'Umar," by rising too high in the bureaucracy and behaving arrogantly. It was only in the nineteenth and especially the twentieth centuries, due to, inter alia, the confrontation of opposing Jewish and Arab nationalisms, that irrational beliefs about the diabolical, malevolent, and all-powerful Jew started to flourish in Muslim

ments," in Middle Eastern Cities: A Symposium on Ancient, Islamic, and Contemporary Middle Eastern Urbanism, ed. I. M. Lapidus (Berkeley: University of California Press, 1969), 80-81. 24 Ashtor, History, 1:328 - 35; 1:350 - 56; 2:105. For Mamluk Syria, see: N. Hofer, “The Ideology of Decline and the Jews of Ayyubid and Mamluk Syria," in Muslim-Jewish Relations in the Middle Islamic Period, ed. S. Conermann (Göttingen: V\&R unipress; Bonn University Press, 2017), 102-3, 114; see also: M. R. Cohen, "Sociability and the Concept of Galut in Jewish-Muslim Relations in the Middle Ages," in Judaism and Islam: Boundaries, Communication and Interaction. Essays in Honor of William M. Brinner, ed. B. H. Hary et al. (Leiden: Brill, 2000), 37-51.

25 Cohen, Under Crescent, 169; Ibn Kathīr, Al-Bidāya wa-l-Nihāya (Beirut: Dār al-Iḥyā' al-Turāth al-'Arabī, 1413/1993), 14:261. This episode was also witnessed by the famous traveler Ibn Batțūta, see: Voyages d'Ibn Batoutah: texte arabe accompagné d'une traduction par C. Defrémery et B. R. Sanguinetti (Paris: 1853), 1:227-29. 
world. These "modern myths of Muslim antisemitism" as termed by Mark Cohen, were mainly "European import," which first found an audience among the Arab Christians of Syria. ${ }^{26}$

An attempt to succinctly evaluate the situation of Egyptian and Syrian Jewry under the Mamluks in the larger perspective of medieval world Jewry brings to mind the saying that everything is relative. Compared to the situation under the Fatimid Caliphate in Egypt and Syria during the eleventh and twelfth centuries, the Jews in the Mamluk period definitely became humiliated and suffered a significant decline. However, compared to their brothers in Christian lands, their situation was considerably good. As opposed to their European co-religionists, even during the oppressive period of Mamluk rule, Jews usually received protection from the authorities for their life and property and for any kind of injustice; they were much more integrated in the general social, economic, and even intellectual life; above all, they were not exposed to abysmal hatred which lead to horrible pogroms and expulsions. Based on Mark Cohen's observation in his summarizing study Under Crescent and Cross, we may say that Jews in the Mamluk Sultanate, and generally in the whole medieval Muslim world, were part of a hierarchical social order, in which they were at the lower level but still an integral part of the general, "Islamicate," society. In Christian Europe, however, Jews were excluded from society. ${ }^{27}$

Dr. Amir Mazor is a researcher of the Mamluk Sultanate in Egypt and Syria (12501517 C.E.) and of Jews under Islam in the Middle Ages. In the recent years, his research largely focuses on representation of Jews in medieval Muslim-Arabic historiography. He is currently a Research Fellow at the Department of Israel Studies, Haifa University.

\section{Bibliography}

Arad, Dotan. "Being a Jew Under the Mamluks: Some Coping Strategies." In Muslim-Jewish Relations in the Middle Islamic Period, edited by Stephan Conermann, 21-39. Göttingen: V\&R unipress; Bonn University Press, 2017.

26 N. A. Stillman, "Anti-Judaism/Antisemitism/Anti-Zionism," in Encyclopedia of Jews in the Islamic World (Leiden: Brill, 2010), 1:221-23, 1:232-35; M. Cohen, "Modern Myths of Muslim AntiSemitism" in Muslim Attitudes to Jews and Israel: The Ambivalences of Rejection, Antagonism, Tolerance and Cooperation, ed. M. Ma'oz (Brighton: Sussex Academic, 2010), 31-47; Stillman, The Jews of Arab Lands, 104-7.

27 Cohen, Under Crescent, 107-20. 
Arad, Dotan. "The Musta'rib Jews in Syria, Palestine and Egypt 1330-1700.” Ph.D. thesis, Hebrew University of Jerusalem, 2013. [Hebrew]

Ashtor, Eliyahu. The History of the Jews in Egypt and Syria under Mamluk Rule. Jerusalem: Mossad Ha-Rav Kook, 1944-1970. [Hebrew]

Ashtor, Eliyahu. "Prolegomena to the Medieval History of Oriental Jewry." Jewish Quarterly Review 50, no. 2 (1959): 147-66.

Ashtor, Eliyahu, and R. Amitai. “Mamluks." In Encyclopedia Judaica, 13:438-41. Jerusalem: Keter, 2007.

Baron, Salo Wittmayer. A Social and Religious History of the Jews. New York: Columbia University Press, 1980.

Ibn Batoutah. Voyages d'Ibn Batoutah: texte arabe accompagné d'une traduction par C. Defrémery et B. R. Sanguinetti. Paris: 1853.

Behrens-Abouseif, Doris. Fath Allāh and Abū Zakariyya: Physicians Under the Mamluks. Cairo: Institut français d'archéologie orientale, 1987.

Cohen, Mark R. "Jews in the Mamlūk Environment: the Crisis of 1442 (a Geniza study, T-S. AS 150.3)." Bulletin of the School of Oriental and African Studies 47 (1984): 425-48.

Cohen, Mark R. "Modern Myths of Muslim Anti-Semitism." In Muslim Attitudes to Jews and Israel: The Ambivalences of Rejection, Antagonism, Tolerance and Cooperation, edited by Moshe Ma'0z, 31-47. Brighton: Sussex Academic, 2010.

Cohen, Mark R. "Sociability and the Concept of Galut in Jewish-Muslim Relations in the Middle Ages." In Judaism and Islam: Boundaries, Communication and Interaction. Essays in Honor of William M. Brinner, edited by Benjamin H. Hary et al., 37-51. Leiden: Brill, 2000.

Cohen, Mark R. Under Crescent and Cross: The Jews in the Middle Ages. Princeton: Princeton University Press, 1994.

Goitein, Shelomo Dov. "Cairo: An Islamic City in the Light of the Geniza Documents." In Middle Eastern Cities: A Symposium on Ancient, Islamic, and Contemporary Middle Eastern Urbanism, edited by Ira M. Lapidus, 80-96. Berkeley: University of California Press, 1969.

Goitein, Shelomo Dov. A Mediterranean Society: The Jewish Communities of the Arab World as Portrayed in the Documents of the Cairo Geniza. Berkeley: University of California Press, 1967-1993.

Hofer, Nathan. "The Ideology of Decline and the Jews of Ayyubid and Mamluk Syria." In Muslim-Jewish Relations in the Middle Islamic Period, edited by Stephan Conermann, 95-120. Göttingen: V\&R unipress; Bonn University Press, 2017.

Ibn Kathīr. Al-Bidāya wa-l-Nihāya. Beirut: Dār al-lhyā̄' al-Turāth al-‘Arabī, 1413/1993.

Kraemer, Joel. "A Jewish Cult of the Saints in Fāțimid Egypt." In L'Egypte Fatimide: son art et son histoire, edited by M. Barrucand, 579-601. Paris: Presses de l'Université de Paris-Sorbonne, 1999.

Lapidus, Ira M. Muslim Cities in the Later Middle Ages. Cambridge: Harvard University Press, 1967.

el-Leithy, Tamer. "Sufis, Copts and the Politics of Piety: Moral Regulation in Fourteenth Century Upper Egypt." In Le développement de soufisme en Égypte a l'époque mamelouke, edited by Richard McGregor and Adam Sabra, 75-119. Cairo: Institute français d'archéologie orientale, 2006. 
Lewicka, Paulina B. "Healer, Scholar, Conspirator: The Jewish Physician in the Arabic-Islamic Discourse of the Mamluk Period." In Muslim-Jewish Relations in the Middle Islamic Period, edited by Stephan Conermann, 121-44. Göttingen: V\&R unipress; Bonn University Press, 2017.

Little, Donald P. "Coptic Conversion to Islam under the Bahri Mamluks, 692-755/1293-1354." Bulletin of the School of Oriental and African Studies 39, no. 3 (1976): 552-69.

al-Maqrīzī, Aḥmad b. 'Alī. Kitāb al-Sulūk li-Ma'rifat al-Duwal wa-al-Mulūk. Cairo: Lajnat al-Ta'līf wa al-Tarjama wa al-Nashr, 1934-1973.

al-Maqrīzī, Aḥmad b. 'Alī. al-Mawā'iẓ wa-l-l'tibār bi-Dhikr al-Khițaț wa-l-Āthār fī Mișr wa-l-Qāhira. Cairo: Bulaq, 1854.

Mazor, Amir. "Jewish Court Physicians in the Mamluk Sultanate during the First Half of the $8^{\text {th }} / 14^{\text {th }}$ Century." Medieval Encounters 20 (2014): 38-65.

Perlmann, K. "Notes on the Position of Jewish Physicians in Medieval Muslim Countries." Israel Oriental Studies 2 (1972): 315-19.

Stillman, Norman A. "Anti-Judaism/Antisemitism/Anti-Zionism." In Encyclopedia of Jews in the Islamic World, 1:221-35. Leiden: Brill, 2010.

Stillman, Norman. The Jews of Arab Lands: A History and Source Book. Philadelphia: Jewish Publication Society of America, 1979.

Stillman, Norman. "The non-Muslim Communities: The Jewish Community." In The Cambridge History of Egypt: 640 -1517, edited by Carl F. Petry, 198-210. Cambridge: Cambridge University Press, 1998. 
